\title{
EKLEZJALNY CHARAKTER EUCHARYSTII W ŚWIETLE VATICANUM II
}

Na wstępie* należy odnotować precyzację metodologiczną pod adresem tematu, a mianowicie, że przy prezentacji Eucharystii w ujęciu Vaticanum II powinno się uwzględniać także naukę soboru trydenckiego. Sobór trydencki bowiem poświęcił co najmniej trzy sesje, by wyłożyć naukę katolicką o Eucharystii i bronić ją przed „nowinkami”, jak to w tym czasie określano w Polsce błędy teologiczne reformacji.

Mając na uwadze dorobek Tridentinum trzeba zauważyć, że wśród 16 dokumentów II soboru watykańskiego nie ma ani jednego, któryby wprost był poświęcony tajemnicy Eucharystii. Niemniej zwraca uwagę fakt, że prawie wszystkie te dokumenty i to niekiedy bardzo często mówią o Eucharystii. Odnosi się to głównie do konstytucji o liturgii świętej. Jedynie trzy z nich nie mają żadnej wyraźnej wzmianki w tym względzie. Są to: dekret o środkach społecznego przekazu myśli, deklaracja o stosunku Kościoła do religii niechrześcijańskich i deklaracja o wolności religijnej. Jeżeli milczenie o Eucharystii zacytowanych deklaracji usprawiedliwia się niejako już samym ich tytułem, to milczenie Dekretu o środkach społecznego przekazu myśli wydaje się być tutaj czymś nieco dziwnym. Wiadomo bowiem, że np. transmisja mszy św. poprzez radio czy telewizję implikuje różne zagadnienia z zakresu teologii dogmatycznej czy pastoralnej.

Z licznych tekstów Vaticanum II na temat Eucharystii wyłaniają się w zależności od przedmiotu formalnego badań - różne tematy wiodące. Chyba nie zawęzi się tematu, tzn. eklezjalnego charakteru Eucharystii, jeżeli ograniczymy się do przedstawienia treści tych tekstów soborowych, które stwierdzają, że Eucharystia stanowi centralną tajemnicę zbawczą wiary chrześcijańskiej i jako taka posiada z Kościołem jedyną w swoim rodzaju więź.

* Poniższy artykuł jest przeredagowanym tekstem referatu, wygłoszonego 9 kwietnia $1987 \mathrm{r}$. na sesji naukowej nt. Eucharystia darem zobowiqzującym, zorganizowanej przez Papieską Akademię Teologiczną w Krakowie. Nadto por.: F. M a rin elli, Eucarestia, [w:] Dizionario del Concilio Ecumenico Vaticano Secondo, ed. S. G a r of a lo, T. Fe de rici, Roma 1969, s. 1118 - 1124. 
Jest to wyraźna nauka Vaticanum II i fakt ten należy już na samym początku podkreślić. Zdaniem soboru Eucharystia stanowi ośrodek promieniowania wszelkiego dobra, którym Bóg obdarza na ziemi człowieka i to nie tylko w porządku nadprzyrodzonym, lecz także w zakresie wartości doczesnych. Może najbardziej reprezentatywna jest tu wypowiedź Dekretu o posłudze i życiu kapłanów: „W Najświętszej Eucharystii zawiera się całe duchowe dobro Kościoła, a mianowicie sam Chrystus, nasza Pascha i chleb żywy, który przez Ciało swoje ożywione i ożywiające Duchem Świętym daje życie ludziom, zapraszając ich i doprowadzając w ten sposób do ofiarowania razem z Nim samych siebie, swojej pracy i wszystkich rzeczy stworzonych" (D 5). Zbawcze działanie Chrystusa w Kościele koncentruje się więc wokół rzeczywistej obecności Ciała i Krwi Pańskiej w Eucharystii. Działanie to, naucza tenże sobór, i co Duszpasterski Synod Archidiecezji Krakowskiej z inspiracji swego biskupa Karola kard. Wojtyły uwydatnił ${ }^{2}$, realizuje się na trzy znane sposoby, a więc poprzez uświęcanie, ewangelizację i pracę pasterską w odniesieniu do Ludu Bożego.

W sposób najbardziej wyrazisty Vaticanum II wyeksponowało prawdę, że Eucharystia stanowi centrum uświęcenia człowieka. Sprawie tej jest poświęcony niejako ex professo cały II rozdział konstytucji o liturgii świętej omawiający Misterium Eucharystii. Utrwalając w Eucharystii Ofiarę Krzyża, Zbawiciel tym samym powierzył Kościołowi na całe wieki aż do swego powtórnego przyjścia „pamiątkę swej Męki i Zmartwychwstania: sakrament miłosierdzia, znak jedności, węzeł miłości, ucztę paschalną, w której pożywamy Chrystusa, w której dusza napełnia się łaską i otrzymuje zadatek chwały" (KL 47). Inaczej mówiąc ludzkie zbawienie dlatego realizuje się poprzez sprawowanie Paschy Chrystusa (por. KL 2, 6, 10, 47, 61, 81, 106), ponieważ Eucharystia jako ofiara sakramentalna jest właśnie sakramentem misterium paschalnego. Pięknie i zarazem bardzo głęboko ujmuje to konstytucja dogmatyczna o Kościele, stwierdzając: „Ilekroć na ołtarzu sprawowana jest Ofiara Krzyżowa, w której «na Paschę naszą ofiarowany został Chrystus» (1 Kor 5,7) dokonuje się dzieło naszego odkupienia" (KK 3). Będąc pamiątką śmierci i zmartwychwstania Chrystusa Eucharystia „odnawia przymierze Boga z ludźmi” (KL 10), stanowi ofiarę „przez którą Chrystus utwierdził Nowe Przymierze we krwi swojej” (DK 4).

Eucharystia przedstawia i zawiera Chrystusa paschalnego z jego śmiercią, zmartwychwstaniem i zasiadaniem po prawicy Ojca (por. KL 2, 6, 7, 33, 102; KK 3, 48; DK 13). W mszy św. liturgia słowa ściśle jednoczy obwieszczenie śmierci i zmartwychwstania Pańskiego oraz odpowiedź na nie słuchającego ludu, a liturgia eucharystyczna, wspominając i czyniąc zarazem obecnym zbawcze wydarzenie Golgoty, jednoczy skutecznie ludzi z Ciałem i Krwią Chrystusa umarłego i zmartwychwstałego. Eucharystia jest więc syntezą wszystkich misteriów, które pośredniczą w Chrystusie mocą Ducha Świętego w zbawieniu 
człowieka; jest Ciałem Chrystusa ożywionym i ożywiającym w Duchu Świętym (por. DK 5). Ona „uobecnia zwycięstwo i triumf Jego śmierci” (KL 6).

Prymat Eucharystii w dziele uświęcenia wywodzi się zatem stąd, że będąc par excellence sakramentem paschalnym, daje moc wszystkim innym sakramentom i sakramentaliom, dzięki którym - o czym uczy konstytucja o liturgii — „prawie każde wydarzenie życia odpowiednio usposobionych wiernych zostaje uświęcone przez łaskę, wypływającą z paschalnego misterium Męki, Smierci i Zmartwychwstania Chrystusa [...]; w ten sposób niemal każde godziwe użycie rzeczy materialnych może zostać skierowane do uświęcenia człowieka i uwielbienia Boga" (KL 61; por. KL 102 - 107). W tym kontekście lepiej widać, dlaczego w Dekrecie o pasterskich zadaniach biskupów w Kościele znajduje się zalecenie pod adresem pasterzy, że powinni „ciągle dokładać starań, by wierni coraz głębiej poznawali i przeżywali poprzez Eucharystię tajemnicę paschalną celem wytworzenia jednego, mocno zwartego Ciała w jedności Chrystusowej milości" (DB 15).

W kwestii związków pomiędzy Eucharystią a ewngelizacją wypowiedziało się Vaticanum II w sposób najbardziej znamienny, mówiąc o obowiązkach prezbiterów. Tekst soborowy naucza, że „głoszenie słowa jest wymagane do samej posługi sakramentów, ponieważ są to sakramenty wiary, która rodzi się ze słowa i nim się karmi. W szczególności odnosi się to do liturgii słowa w odprawianiu mszy świętej [...], w której to ofierze uczestniczą wierni modlitwą i przyjmowaniem sakramentów" (DK 4). Najskuteczniejszym przepowiadaniem jest przepowiadanie liturgiczne, ponieważ zapewnia obecność samego Chrystusa, który wprawdzie „zawsze jest obecny w swoim Kościele”, ale „szczególniej w czynnościach liturgicznych” (KL 7). „W liturgii bowiem Bóg przemawia do swego ludu, Chrystus w dalszym ciągu głosi Ewangelię, lud zaś odpowiada Bogu śpiewem i modlitwą" (KL 33). Inaczej mówiąc, liturgiczna celebracja Eucharystii ma sobie tylko właściwą komplementarność. To, co jest zwiastowane w liturgii słowa, znajduje zarazem pełną swoją realizację w liturgii eucharystycznej, ponieważ obie te liturgie zajmują się tym samym misterium: ten sam bowiem Chrystus jest obecny najpierw poprzez Słowo a następnie pod postaciami eucharystycznymi.

Vaticanum II mówi wreszcie, że Eucharystia powinna stanowić centrum pracy duszpasterskiej w Kościele. Podstawowe zasady w tym względzie sformułowała konstytucja o liturgii, gdzie się naucza, że choć liturgia nie wyczerpuje całkowicie wszelkiej działalności Kościoła, to jednakże jest szczytem, do którego ona zmierza i zarazem źródłem, z którego płynie wszelka jego moc. Głównym celem troski duszpasterskiej jest, by ludzie stali się dziećmi Bożymi poprzez wiarę i przyjęty chrzest oraz by się zgromadzali w Kościele, chwaląc Boga uczestnictwem w ofierze i stole Pańskim (por. KL 9, 10). Stąd nie można nigdy nie doceniać wychowania liturgicznego i czynnego uczestnictwa w liturgii. „Liturgia bowiem jest pierwszym i niezastąpionym źródłem, z którego wie- 
rni czerpią ducha prawdziwie chrześcijańskiego” (KL 14). „Z liturgii też, a głównie z Eucharystii jako ze źródła, spływa na nas łaska i z największą skutecznością przez nią dokonywa się uświęcenie człowieka w Chrystusie i uwielbienie Boga, które jest celem wszystkich innych dzieł Kościoła” (KL 10).

W konkluzji powiemy, że zbawcze działanie Chrystusa-Kapłana, Proroka i Króla szczególniej dochodzi do głosu przy sprawowaniu Eucharystii. Lud Boży zawdzięcza swoją specyfikę bycia Mistycznym Ciałem Chrystusa właśnie Eucharystii.

\section{SZCZEGÓLNE ZWIĄZKI EUCHARYSTII Z KOŚCIOŁEM}

Problem ten rzuca się w oczy nawet przy pobieżnej lekturze tekstów Vaticanum II. Więcej nawet! Stanowi jeden ze znamiennych rysów eklezjologii soborowej. Dekret o ekumenizmie stwierdza lapidarnie: „W Kościele swoim Chrystus ustanowil przedziwny sakrament Eucharystii, który oznacza i sprawia jedność Kościoła” (DE 2). Mówiąc o komunii świętej konstytucja o Kościele zauważa: „Przy łamaniu chleba eucharystycznego, uczestnicząc w sposób rzeczywisty w Ciele Pańskim, wznosimy się do wspólnoty z Nim i nawzajem ze sobą (...). Tak oto wszyscy stajemy się czlonkami owego Ciała (por. 1 Kor 12,27), a «brani z osobna jesteśmy członkami jedni drugich $(\mathrm{Rz} 12,5) »(\mathrm{KK} 7)$. I może jeszcze jeden cytat $\mathrm{z}$ konstytucji o liturgii, wyjątkowo ważny, ponieważ poprzedza w tym dokumencie definicję Kościoła: „Liturgia, przez którą - szczególnie w boskiej Ofierze Eucharystycznej - dokonuje się dzieło naszego Odkupienia - w najwyższym stopniu przyczynia się do tego, aby wierni życiem swoim wyrażali oraz ujawniali innym misterium Chrystusa i rzeczywistą naturę prawdziwego Kościoła” (KL 2).

Tak więc sobór niejako na nowo, a w każdym razie z dużą stanowczością i siłą, odkrył i ukazał w swoim nauczaniu więzi między Eucharystią a Kościołem. Te związki są tak głębokie, że właściwie nie można w ogóle nic istotnie ważnego powiedzieć o Kościele, jeżeliby się pominęło Eucharystię: dostrzegalny znak, ale i zarazem nadprzyrodzoną rzeczywistość jedności eklezjalnej. W sformułowaniu konstytucji o Kościele brzmi to następująco: „W sakramencie chleba eucharystycznego uprzytamia się i dokonuje jedność wiernych, którzy stanowią jedno ciało w Chrystusie (por. 1 Kor 10,17)" (KK 3). Oczywiście odnosi się to nie tylko do Kościoła jako boskiego misterium - o ile jest on „mistycznym Ciałem Chrystusa”, „wspólnotą duchową”, „Kościołem bogatym w dary niebiańskie” - lecz także do „Kościoła ziemskiego”, będącego „hierarchiczną społecznością" i „widzialnym zrzeszeniem” (por. KK 8). Eucharystia sprawia bowiem coraz pełniejsze włączenie wiernych we wspólnotę Kościoła poprzez zjednoczenie z Chrystusem. Więzią jedności jest tu nie kto inny tylko eucharystyczny Chrystus. „Uczestnicząc w Ofierze eucharystycznej - czyta- 
my w Konstytucji dogmatycznej o Kościele - [wierni] posileni w świętej komunii Ciałem Chrystusowym, w konkretny sposób przedstawiają jedność Ludu Bożego, której stosownym znakiem i cudowną przyczyną jest Najświętszy Sakrament" (KK 11).

Tak więc Chrystus pragnął mieć Eucharystię w Kościele i poprzez Kościół . Człowiek otrzymuje laskę, będącą własnym skutkiem Eucharystii, jeżeli uczestnicząc we wspólnocie Kościoła, spożywa Ciało i Krew Chrystusa. Przyjmując Eucharystię czyni wtedy widzialną wspólnotę Kościoła, który składa ofiarę z Chrystusa. Stąd Eucharystii nie wolno traktować na równej płaszczyźnie $\mathrm{z}$ innymi sakramentami, ponieważ w niej „jest sprawca świętości” (DS 1639; por. DS 1803).

Wprawdzie każdy z sakramentów ma także własną odnośnię do Kościoła, swój własny wymiar eklezjalny, lecz jest on zawsze niejako zawężony do szczególnego czy jednostkowego aspektu. Słusznie mówi się, że sakramenty realizują Kościół, oczywiście każdy sakrament na swój sposób przez sobie właściwą laskę. Niemniej charakter eklezjalny Eucharystii jest zasadniczo pełniejszy, ponieważ w żadnym innym sakramencie więź między Chrystusem i Kościołem nie jest tak ścisła, jak właśnie w niej.

W związku z tym należy tutaj uwypuklić podwójną funkcję eklezjalną Eucharystii: pierwsza polega na osobistym zbliżeniu człowieka do Chrystusa w Jego ciele i krwi, które po wsze czasy powierzył Kościołowi, druga sprowadza się do uczestnictwa w Mistycznym Ciele Chrystusa, którym jest Kościół. Jest to więc spotkanie z Chrystusem w jego ciele sakramentalnym i jego krwi sakramentalnej, i z Chrystusem w Ciele Mistycznym, gdzie zbliżenie Chrystusa i Kościoła osiąga granicę prawie że tożsamości. Osobiste spotkanie wiernych z Chrystusem dokonuje się w komunii świętej. Równocześnie jednak dzięki komunii człowiek wrasta w samo życie Kościoła, staje się uczestnikiem tego życia, ponieważ wchodzi w misterium jedności Chrystusa z Kościołem.

W tym kontekście należy jeszcze podnieść relację Eucharystii względem jedności chrześcijan w ramach ruchu ekumenicznego. Eucharystia jawi się tutaj przede wszystkim jako znak utraconej jedności. Im więcej chrześcijanie spostrzegają swoje zróżnicowanie w kwestii Eucharystii, która powinna być źródłem jedności, tym boleśniej odczuwają zaistniałe między sobą podziały. Stan rozdarcia pod tym względem trafnie charakteryzuje Dekret o ekumenizmie: „Wszyscy wyznają, że są uczniami Pana, a przecież mają rozbieżne przekonania i różnymi podążają drogami, jak gdyby sam Chrystus był rozdzielony" (DE 1). Mimo to Eucharystia w dalszym ciągu pozostaje znakiem nadziei na jedność, a nawet boskim lekarstwem jedności, choć w ograniczonym znaczeniu. W Kościołach Wschodnich, podobnie jak w Kościele Katolickim, uczy Dekret o ekumenizmie „poprzez sprawowanie Eucharystii Pańskiej (...) buduje się i wzrasta Kościół Boży, a przez koncelebrację przejawia się ich wspólnota" (DE 15). Jeżeli idzie o Kościoły i społeczności kościelne odłączone na Zacho- 
dzie, które — jak tenże dekret wyraźnie stwierdza — „nie przechowały właściwej i całkowitej rzeczywistości eucharystycznego misterium, głównie przez brak sakramentu kapłaństwa, to jednak sprawując w świętej Uczcie pamiątkę śmierci i zmartwychwstania Pańskiego, wyznają, że oznacza ona życie w łączności z Chrystusem i oczekują Jego chwalebnego przyjścia" (DE 22). Stąd i tutaj w nauce o Uczcie Pańskiej istnieją punkty styczne, mogące służyć za wspólną płaszczyznę dialogu.

W sumie Eucharystia oznacza dla Kościoła jego najdoskonalszą realizację. Nigdzie bowiem Kościół nie występuje tak wyraźnie jako przez Boga powołany Lud, który wokół Chrystusa się zgromadza, jak właśnie w celebracji Wieczerzy Pańskiej. Gdzie kielich Pana jest wypijany, tam urzeczywistnia się we Krwi Chrystusa nowe Przymierze (por. 1 Kor 11,25) gdzie eucharystyczny chleb zostaje połamany i rozdany wiernym, tam wielu staje się widzialnie jednym Ciałem (por. 1 Kor 10,17). Dlatego, niejako zgodnie ze swoją naturą, Eucharystię powinno się sprawować publicznie w zgromadzeniu wiernych. Ale należy i to podkreślić - gdy jest sprawowana bez obecności Ludu Bożego pozostaje także zgodnie ze swoją najgłębszą istotą Eucharystią całego Kościoła. I chyba jest coś z prawdy w twierdzeniu, że zmiana w sposobie odprawiania mszy św. ukazuje do pewnego stopnia zmiany zachodzące w świadomości Ludu Bożego co do obrazu Kościoła.

Przytoczmy jeszcze parę myśli, które syntetyzują poprzez teksty Vaticanum II istotne elementy eklezjalnego wymiaru Eucharystii. Uczestnicząc w Wieczerzy Pańskiej chrześcijanie posilają się „przy stole Ciała Pańskiego” (KL 48). Pożywając Wieczerzę Pańską i obwieszczając śmierć Pana aż przybędzie (por. KL 6) w tym sakramencie wiary mają pożywienie zostawione im przez Boga na drogę i przedsmak uczty niebiańskiej, przeżywają braterskie zespolenie z Chrystusem i między sobą (por. KDK 38). Aspekt uczty jest ściśle zjednoczony z charakterem ofiarnicżym. Soborowe wyrażenie „ofiara eucharystyczna" (por. KL 2, 27; KK 10, 11, 17, 45, 50; DB 30; DFK 4; DM 15; DK $2,13,14)$ jest tym, które po wielekroć wraca i które oznacza ciągłość i tożsamość nauki o Eucharystii w użyciu Tridentinum i Vaticanum II.

\section{LA DIMENSION ECCLESIALE DE L'EUCARISTIE A LA LUMIERE DU VATICAN II}

\section{Résumé}

En se basant sur les textes conciliaires l'auteur présente: $1^{\circ}$ l'Eucaristie comme le mystère central de la mission salvifique de l'Eglise; $2^{\circ}$ les liens spécifiques entre l'Eucaristie et l'Eglise. Au point de vue méthodologique il faut mettre en relief que cette doctrine, dispersée dans les différents documents de Vatican II, reste en continuation avec celle du Concile de Trente. 